\title{
THE DISCOURSE OF SPIRITUALITY VERSUS RELIGIOSITY IN ISLAM
}

\author{
Idi Warsah \\ IAIN Curup, Bngkulu \\ Email: idiwarsah@iaincurup.ac.id \\ $\underline{\text { Imron }}$ \\ Universitas Muhammadiyah Magelang \\ Email:imron1807yes@ummgl.ac.id
}

\begin{abstract}
This article discusses spirituality and religiosity. Spirituality and religiosity are two of the most basic aspects of mentality and human belief, which according to most people are the goal of human existence in the world. These two terms are widely understood by people as something that has the same meaning and understanding. But actually has a different meaning. Spirituality is an experience or desire to know God that is done personally by seeing things deeper, substantially and seeking real understanding. Whereas religiosity is the appreciation and experience of individuals towards the teachings of religion or the beliefs they hold. Therefore, in essence, religiosity is a pattern of values, beliefs, symbols, behavior and experience that is institutionalized, which is directed at spirituality. In this case religiosity is actually a means of achieving spirituality.
\end{abstract}

Keywords: Discourse; Spirituality; Religiosity.

\section{INTRODUCTION}

The definition of religiosity is still a controversy up to the present. Meanwhile, the spirituality and religiosity are fundamental aspects of human mentality and belief that, according to most people, constitute the purpose of the existence of human in this world. These two terms are often considered as having similar definition and interpretation, whereas they have different meaning. Generally, the experts of psychological study failed to make a consensus of the definition of religiosity and spirituality therefore both of them are identified as two different things, and their operational usage often overlaps. The study about religiosity had been begun in 1990's and this was marked by the publication of "Journal for the Scientific Study of Religion and Review of Religious Research" an international journal for the psychology of religion (Fridayanti, 2015: 199208).

The concept of spirituality in the discipline of psychology of religion emerged 
during the discussion of religiosity, and eventually became a problem of indistinct relationship between religiosity and spirituality which caused confused definition of religiosity and spirituality (Fridayanti, 2015: 199-208). Thus, this article tries to address spirituality and religiosity along with their adhere characteristics. To continue the exploration, I will begin with providing the concept of spirituality. The elaboration of the concept of spirituality in the following section covers its nature, scope and dimension in Islamic perspective with more focus on its relevant to the discourse of religiosity.

\section{CONCEPT OF SPIRITUALITY}

\section{The Nature of Spirituality}

The term 'spirituality' is derived from the word 'spirit' which means soul (Poerwadarminta, 1986: 963). The term is also defined as an oriented philosophy action in which all activities are done for the sake of Allah and happiness of soul (Leeming, 2014: 872). It contains a definition of relationship between human and God (As'ad, 2004: 340). Spirituality is an experience or interest to recognize God personally through deep substantial view and actual understanding (Harahap, 2011: 6). It is an activity with true immortal spiritual ending, and is not for a while (Tobroni, 2005: 19-20). It is an encouragement for all human actions (Suaedy, 2004: 202), and basic feeling of interaction with oneself, other people, and universe. It is said as a step to find continual authentic holistic deep meaning of self-existence related to sacred transcendent things (Karakas, 2010: 89-106).

Elkins (1988) defines spirituality as a way to become something and undergo an event originated from awareness of transcendent dimension which has some characteristic values that can be recognized by an individual, life, and everything considered as the divine authority. Spirituality is a presence of relationship with the mighty power determining the way of how one lives his life (Armstrong, 1995: 3). Further, Tart states that spirituality is a wide potential of human final destination with higher entity, God, love, affection, and purpose (Tart, 1975: 4). According to several definitions above, it can be concluded that spirituality is all philosophical oriented good deeds intended to make effort to possess transcendent value for the sake of Allah. It suggests that, essentially, every human action must have good goal and transcendent value.

\section{Spirituality in Islamic Perspective}

As explained earlier, spirituality is an action conducted based on the awareness of Allah and happiness of soul (Leeming, 2014: 872) or relationship between 
human and God (Imron, 2016: 3) so that spirituality is a fundamental and natural element in human life as indicated in the Quran Surah Ar-Rum verse 30.

Translation: "turn your face singlemindedly to the true Faith and adhere to the true nature on which Allah has created human beings. The mould fashioned by Allah cannot be altered. That is the True, Straight Faith, although most people do not know."

Mustafa Al Maraghi, as quoted by Jalaluddin and Ramayulis (1998: 72). interprets the above verse as follows: be consistent, you, to all characters prescribed by Allah in the inside of human being, because, indeed, Allah who creates human according to his nature that is inclined to tawheed teaching and believe it based on what shown by mind and lead him to common sense. Human was created by Allah with the instinct of having religion, tawheed. Transcendent bond is human characteristic that has felling of being religious which is then called as spirituality (Imron, 2018: 34). Spirituality is a personal experience or intention to recognize God by seeing something deeply and substantially, and searching true understanding that is not only the surface and short term (Harahap, 2011: 6). Besides, it is a deep interpretation of the world existence, and all activities are committed for the almighty Allah (Hafidzuddin, 2003:5).

Nasr (2004: 185) affirms that human and all his activities and characteristics cannot be separated from the dimension of divinity. Attaining knowledge about the nature of human can be through religious texts studies. Yet human tends to ignore them, hence he does not know the meaning of spiritual wisdom in his life. The uniqueness of human existence was associated with his relationship with Allah as mentioned by the Qur'an surah Al-A'raf verse 172.

Interpretation: And recall (O Prophet) when your Lord brought forth descendants from the loins of the sons of Adam, and made them witnesses against their ownselves. asking them: 'Am I not your Lord?' They said: 'Yes, we do testify.' We did so lest you claim on the Day of Resurrection: 'We were unaware of this.

The contract made before the birth of human brought about responsibility along with its benefits and dangers for human as an intelligent free will (Nasr, 2004: 21). The mandate granted by Allah to human contains the confession of the oneness of Allah and commitment to perform ibadah thus accepting the mandate means wiliness to worship and obey Him (Nasr, 2004: 338). Then, according to Nasr the nature of spirituality is a form of relationship with and dependence on the Creator, as mentioned in the Qur'an surah Al-Hajj verse 5, 
surah Adz-Dzariat verse 56, surah Al-An'am verse 162, surah Maryam verse 65, surah Al-Zalzalah verse 7-8.

Interpretation: "O mankind! If you have any doubt concerning Resurrection, then know that it is surely We Who created you from dust, then from a drop of sperm, ${ }^{5}$ then from a clot of blood, then from a little lump of flesh, some of it shapely and other shapeless. (We are rehearsing this) that We may make the reality clear to you. We cause (the drop of sperm) that We please to remain in the wombs till an appointed time. We bring you forth as infants (and nurture you) that you may come of age. Among you is he that dies (at a young age) and he who is kept back to the most abject age so that after once having known, he reaches a stage when he knows nothing. ${ }^{7}$ You see the earth dry and barren and then no sooner than We send down water upon it, it begins to quiver and swell and brings forth every kind of beauteous vegetation."

Interpretation: "I created the jinn and humans for nothing else but that they may serve Me."

Interpretation: "Say: 'Surely my Prayer, all my acts of worship, and my living and my dying are for Allah alone, the Lord of the whole universe."

Interpretation: "He is the Lord of the heavens and the earth and all that is in between. Serve Him, then, and be constant in serving Him. Do you know anyone that might be His compeer?"

Interpretation: "So whoever does an atom's weight of good will see it. (7) And whoever does an atom's weight of evil will see it."

The verses depict the spirituality as a sort of obedience of an individual toward Allah in which all his activities are aimed to worship Allah and all what he done will be rewarded by Allah. It is what human soul needs as creature that has dimension of spirit inside his physical. Viktor Frankle in Bastaman says that the existence of human is shown by three factors: spirituality, freedom, and responsibility (Bastaman, 1995: 36). Kuntowijoyo states that behavior of good spiritual human shows prophetic character that has three pillars: (1) ta'muruuna bil ma'ruuf, (2) tanhauna 'anil munkar, (3) tu'minuuna billaah. These pillars are interpreted into universal language as concept of humanity, liberation, and transcendence (Kuntowijoyo: 2007: 99).

\section{Scope of Spirituality}

According to Miliman (2003: 426-447), spirituality in the context of workplace comprises several levels; individual level, group level, and organizational 
level. Each level has three main dimensions: purpose in one's work or meaningful work, having a sense of community, and being in alignment with the organization's values and mission. Meanwhile, Pawar Shankar mentions two level of spirituality of workplace: individual level and organizational level (Shankar, 2008:544-567). Individual level is fundamental aspect of spirituality of workplace. It is an individual feeling to sense deepest meaning and purpose of one's profession. This dimension represents how an employee interacts with his work from day to day. It involves the deepest sense of meaning and purpose of one's job.

Expression of spirituality of workplace assumes that everyone has motivation and interest to engage in every beneficial action for himself and other people. Spirituality does not only view profession as something joyful and challenging but also something that has meaning and deepest goal: making one's dream come true, fulfilling one's needs, and giving contribution to others (Shankar, 2008:544-567). Group level refers to level of human behavior and focuses on interaction between an employee and his partners. The spirituality of this level consists of mental relationship, emotional relationship, and spiritual relationship of a team or group in an organization, and the core of this community is a human relationship including support, freedom of expression, and protection (Shankar, 2008:544-567). Organizational level shows individual experience which is associated with strong relationship between their personal values and mission, and purpose of an organization. It is related to the premise that the goal of the organization is more important than one's interest so that someone has to give contribution to his community or other parties (Shankar, 2008:544-567).

Further, Giacalone and Jurkiewichz as quoted by Nurtjahyani (2010: 2730)) state that scope of spirituality includes two levels: individual level and organizational level. The first level refers to collection of individual values that spur transcendent experience though working process, and facilitate both sense of being connected with other people and sense of being completed and happy. Individual level is fundamental aspect of spirituality of workplace comprises ability to sense deepest meaning and purpose of one's profession. This dimension depicts how an employee interacts with his work from day to day. This is based on an assumption that human has deepest motivation, truth, and passion to commit beneficial activities for himself and other people. Besides, spirituality does not only view profession as something joyful and challenging but also something that has meaning and deepest goal: making one's dream come true, fulfilling one's needs, and giving contribution to others (Milliman, 2003: 426-447). The second, organizational level refers to working 
frame of cultural values of an organization that motivate transcendent experience of employee through working process in order to facilitate sense of being connected with other people, and being completed and happy. Spirituality of work of this level is related with vision and cultural values of the organization (Nurtjahjani, 2010: 27-30).

\section{Dimensions of Spirituality}

Milliman (2003: 426-447) mentions indicators of individual dimension of spirituality of workplace as follows: 1) work is aimed to make other people happy; 2) work is done to arouse motivation; 3) work is related to an important thing of life; 4) effort to be diligent and avoidance of working absence; 5) work is associated with social and community kindness; 6) work is personally meaningful. Danah Zohar refers spirituality as spiritual quotient, then he and Marshall state that the spiritual quotient comprises: 1) ability to be flexible, 2) possession of high awareness, 3 ) ability to bear face and make use of sufferings; 4) ability to bear face and bear pain, 5) possession of vision and values of life, 6) reluctance of doing unnecessary activity; 7) ability to see emerging problem through different viewpoints; 8) possession of preference of questioning for gaining fundamental answer; and 9) possession of independence in completing tasks (Zohar \& Marshall, 2007: 14).

Further, Elkins (1988: 5-18) formulates dimension spirituality in some dimensions. First, it is a transcendent dimension namely a concept which states that there is a transcendent thing in this life (beyond human reason). The core of this belief is various beginning with traditional psychology view that the God exists privately. Then, the transcendent dimension is no more than just a natural self-awareness of the existence of bigger essence. Yet the typology, metaphor, and model to describe transcendent dimension believe that not all invisible dimensions have material shape. He trusts the existence of "invisible world" and makes harmonious relationship with transcendent dimension; this is beneficial for him. Spirituality is a condition in which someone experiences/senses the presence of the transcendent dimension that is what Maslow said as "peak experience"; he obtains personal strength from this dimension (Elkins, 2013: 34-35). Wahyuningsih explains that spiritual man has strong belief in the existence of transcendent dimension in this life. This belief can be in the form of traditional/religious perspective on God, and psychological perspective on the transcendent dimension as natural existence of self-awarness of unawareness area or greater self. Such a spiritual man has transcendent experience (peak experience) (Wahyuningsih, 2009: 116-129).

Second, meaning and purpose in life is searching of meaning and purpose 
of lie, and based on that the belief of life will be truly meaningful like the existence of someone who has goals. This basis is varied from one to another person, yet there is an agreement that each person fills existential inanition with authentic awareness that life possesses meaning and purpose (Elkins, 2013: 34-35). It can be said more simply that dimension of meaning and purpose of life constitute feeling of having meaning and purpose of life that appear from the belief that life is very meaningful and one will be existed if he has purpose of life (Wahyuningsih, 2009: 119). Third, mission in life is an awareness of job vacancy in which it has responsibility of life, a call that must be replied; a mission that must be carried out; and a destiny must be fulfilled. This life is metamotivated by sacrificing life one can get this (Elkins, 2013: 34-35). Simply, it suggests that he has responsibility for this life, and is encouraged by meta motivation (Wahyuningsih, 2009: 119).

Forth, sacredness of life (dimension of sacredness of life) is that life is sacred, conscious, adored, amazed, miraculous, though atheistic. It divides life into purity and secularity; ukhrawi and profane, but all agree that life is sacred and remarkable. A spiritualist can sanctify and involve religion in all elements of life (Elkins, etc, 1988: 10-12). Simple definition of sacred dimension is that life must be infused by purity, khidmad, takzim, and admiration though in nonreligious setting. He believes that the end of his life is akhirat, and holiness is a must (Wahyuningsih, 2009: 119). Fifth is material value, meaning that material things are valued but not sought as the end of spiritual pursuits. A spiritualist respects all material elements such as money and opulence, but they are not his final searching; he does not also use them to substitute unfulfilled religious necessity. He knows that oncologic thirstiness cannot be relieved by material aspects but it can only be fulfilled with spiritual elements (Elkins, 2013: 34-35). Dimension of life satisfaction is a form of spiritual satisfaction in the inside an individual; a concept of life that it is not only seen from material aspects (Wahyuningsih, 2009: 119).

Six is altruism (altruism dimension). A spiritualist believes that all of us are guardian of brotherhood, and we feel painful when other are hurt. He has an awareness of social justice and a commitment to love and altruistic action. This dimension believes that human cannot live alone since he is part of life in this word universally (Elkins, 1988: 10-12). Altruism understands that all people are bother, interconnected to others' sufferings, and committed to love and good behavior (Wahyuningsih, 2009: 119). Seventh is idealism (idealism dimension). This dimension views spiritualist as a progressive man committed to the betterment of the world. He loves something in the way it is, and because of its potential in all aspects of life. Spiritualist is committed 
to high idealism and actualization of the potential power in every aspect of life (Elkins, 2013: 34-35). Wahyuningsih explains about idealism dimension in which it sees progressive person as those who has commitment to create better world through high idealism and potential actualization in all aspects of life (Wahyuningsih, 2009: 119).

Eighth is awareness of the tragic (dimension of awareness of the tragedy). It is an awareness of the tragedy of human existence. Someone is definitely aware that he will be sick, suffering, and death. This consciousness is very deep inside his spirituality so that he has existential awareness of facing life. But, there is little paradox in which awareness of tragedy will increase happiness, appreciation, and respect of life. The yield of spirituality is real life effect of relationship between spiritualist and other person, nature, life and other meaningful aspects (Elkins, 2013: 34-35). Dimension of awareness of suffering can be defined simply as an awareness of affliction and death which makes someone more seriously live his life, and the emerging affliction is considered as the test of life (Wahyuningsih, 2009: 119). Ninth is fruit of spirituality that are remnants or atsars that someone has in his life. Spirituality will bring about goodness for his life (Wahyuningsih, 2009: 119).

\section{CONCEPT OF RELIGIOSITY}

The word "religiosity" is derived from the word "religious' means pity or devotion to religion. The world "religion" is derived from Latin word "religio" which is rooted from "religare" means binding. It means compulsories or rules must be conducted in order to tie up and unite an individual or community in the relationship with God, other people and surroundings (Driyarkara, 1987: 29). Next, the word "religio" is defined as religion, and the definition of the term "religion" is the belief of the existence of God and rules of human behavior. This is in line with Michel Mayer's statement as quoted by Nashori (2002: 68) that religion is a set of rules and definite belief to guide human actions in relationships with God, other people and himself. The term religiosity (religious sity) emerges from both word "religion" and "religio". Religiosity is the barometer of one's knowledge, belief, worship, and devotion to his religion (Nashori, 2002: 71). Dister defines religiosity as the presence of religious internalization in the inside of an individual (Anggarasari \& Ekaningdyah, 1997: 15-20). Meanwhile, according to Zakiyah Darajat, religiosity constitutes feeling, mind, and motivation that encourage religious behavior (Daradjat, 2005: 13).

Every religious attitude is defined as conscious willingness behavior that accepts and agrees with descriptions inherited by community to a person, and then make is as his own belief which is embodied in daily life behavior (Nikko, 
1989: 10). Therefore, religious person is a man whose all mental structure are led to the creator of absolute value, God, the highest and satisfactory giver (Adisubroto, 1987: 23). From the mentioned argumentations, it can be inferred that religiosity is full comprehension and individual experience about religious teaching or belief. It is also defined as a condition in the inside of an individual that motivates him to behave, pose, and act according to religious teaching.

According to Glock and Strak in Nasori, as quited by Ancok and Suroso (2005: 46-48), religiosity has some dimensions. Ideology dimension or belief is a dimension of religiosity related to what must be believed such as belief in God, angels, heaven, and so forth. Ritual dimension is a dimension of religiosity related to behaviors that ruled by religion such as the rule of worship, baptism, shrift, fasting, salah, or special rituals performed in holly days. Dimension of full comprehension is a dimension of religiosity related to religious sense undergone by believers, or how much someone can comprehend experiences in religious ritual for instance, concentration when performing salah. Dimension of Knowledge is a dimension of religiosity related to comprehension and knowledge of religious teachings. Dimension of experience is a dimension of religiosity related to effects of application of religious teachings in daily attitude and behavior.

\section{ARE SPIRITUALITY AND RELIGIOSITY SIMILAR?}

The discussion of spirituality and religiosity is very interesting since they have different constructs according to experts' definitions. The presence of spirituality concept in psychological study caused the degradation of concept of psychological religiosity. Pargament et al. state that the definition of religiosity has been specified as a system of ideology, organization, and ritual in which previously it was defined as all full comprehensions of one's religiosity (Fridayanti, 2015: 3). Viewed from the definition and indicators, spirituality refers to spirit and behavior in which spirit is connected with good energy of physical and psychology. This is in accordance with Karakas statement: spirituality is basic sense of relationship with oneself, other people, and whole universe. Spirituality is considered as a step to find authentic holistic continual deep definition of self-awareness that associated with sacred elements and transcendence (Karakas. 2010: 7)

Meanwhile, the definition of religiosity is a particular practice of behavior related to belief which is legalize by religious institution. Mayer (in Nashori, 2002: 68) affirms that religiosity is a set of rule and definite belief to guide human to behave in front of God, other people, and himself. It is also defined 
as knowledge, belief, implementation of ibadah, and full comprehension of religion (Nashori, 2002: 71); it is a religious internalization aspect in the inside of individual (Anggasari, 1997: 16); it is a sense, thought, and motivation that lead to religious behavior (Daradjat, 2005: 13). Therefore, the character of religiosity is formal institutional since it reflects commitment toward belief and practices according to particular tradition (religion), while spirituality is associated with functional personal experience as the reflective effort of an individual in obtaining purpose and meaning of life (Amir, 2016: 67-73).

Religiosity can be described as a consistency of religion as cognitive element, religious sense as effective element, and religious behavior as psychometric element (Imron). Thus religiosity is a complex integration of religious knowledge with religious sense and behavior in the inside of an individual. Meanwhile, spirituality is a way of being and experiencing something caused by the awareness of the existence of transcendent dimension which is shown by particular good values in the inside an individual, other people, nature, life, and anything considered as the truth" (Amir, etc, 2016:67-73). The presence of spirituality concept in psychological study caused "the degradation of status" of psychological religiosity. The definition of religiosity has been specified as a system of ideology, organization, and ritual in which previously it was defined as all full comprehensions of one's religiosity (Fridayanti, 2015: 199208). Therefore, religion is a pattern of value, belief, symbol, behavior, and experience intuited and led to spirituality. (Amir, etc, 2016: 67-73). In short, the actual definition of religiosity is a mean to achieve spirituality.

\section{CONCLUSION}

The discourse of spirituality versus religiosity has been important to the life of people who practice religion in their daily life. In Islam, the important of the discourse has also influenced the way those believers understand their religious teaching. Several points are highlighted as to support the important of the discourse of spirituality versus religiosity in Islamic perspective. First, spirituality is all philosophic oriented good deed of one who tries to be meaningful and has transcendent values in the only obedience toward Allah. Spirituality is every human action that has noble purpose and transcendent value. Second, religiosity is related to one's knowledge, belief, ibadah performance, and religious comprehension. In other words, religiosity is the presence of religious internalization in the inside of an individual. Third, religiosity is a pattern of value, belief, symbol, behavior, and experience intuited and led to spirituality. In short, the actual definition of religiosity is a mean to achieve spirituality. 


\section{BIBLIOGRAPHY}

Adisubroto, D. (1987). Orientasi Nilai Orang Jawa Serta Ciri-Ciri Kepribadiannya. Yogyakarta: Fakultas Psikologi UGM.

Amir, Y., \& Lesmawati, D. R. (2016). Religiusitas dan Spiritualitas: Konsep yang sama atau Berbeda. Jurnal Ilmiah Penelitian Psikologi: Kajian Empirik \& non Empirik, 2(2), 67-73.

Ancok, D. \& F.N. S. (2005). Psikologi Islam. Yogyakarta: Pustaka Pelajar.

Anggasari. (1997). Hubungan Tingkat Religiusitas Dengan Sikap Konsumtif pada Ibu Rumah Tangga. Jurnal Psikologi no.4 th II, Yogyakarta.

Armstrong, T. D. (1995). Exploring Spirituality: The Development of the Armstrong Measure of Spirituality. Paper Tresented at The Annual Convention of The American Psychological Association, New York, NY.

As'ad M. U. \& M. H. R. (2004). Spiritualitas dan Modernitas antara Konvergensi dan Devergensi. Spiritualitas Baru, Agama \& Aspirasi Rakyat, Elga Sarapung (ed.) Yogyakarta: Pustaka Pelajar.

Bastaman, H. D. (2001). Integrasi Psikologi dengan Islam: Menuju Psikologi Islami. Yogyakarta: Pustaka Pelajar.

Daradjat, Z. (2005). Ilmu Jiwa Agama. Jakarta: Bulan Bintang.

Driyarkara, N. (1987). Percikan Filsafat. Jakarta: Pembangunan.

Elkins, David, N., Hedstrom, L. J., Hughes, L. L., \& Leaf, J.A. (1988). Toward a Humanistic Phenomenological Spirituality: Definition, Description, and Measurement. Journal of Humanistic Psychology, 28 (4), 5-18.

Elkins, D. N. (2013). Beyond Religion: A Personal Program for Building a Spiritual Life Outside the Walls of Traditional Religion. India: Quest Books Publisher, Theosophical Publishing House.

Fridayanti, F. (2015). Religiusitas, Spiritualitas Dalam Kajian Psikologi dan Urgensi Perumusan Religiusitas Islam. Psympathic: Jurnal Ilmiah Psikologi, 2(2), 199-208.

Hafidzuddin, D. \& Hendri, T. (2003). Manajemen Syariah dalam Praktek. Jakarta: Gema Insani Press.

Harahap, S. S. (2011). Etika Bisnis dalam Perspektif Isla. Jakarta: Salemba Empat.

Imron. (2018). Aspek Spiritualitas dalam Kinerja. Magelang: Unimma Press.

Jalaluddin \& Ramayulis. (1998). Pengantar Ilmu Jiwa Agama. Jakarta: Kalam Mulia. 
Karakas, F. (2010). Spirituality and Performance in Organizations: a Literature Review. Journal of Business Ethics, (2010). 94(1).

Kuntowijoyo. (2007). Islam sebagai Ilmu: Epistemologi, Metodologi, dan Etika. Yogyakarta: Tiara Wacana.

Leeming, David A., Kathryn, M., Stanton, M. (Eds.). (2014). Encyclopedia of Psychology and Religion. New York: Springer Reference.

Milliman, J., Czaplewski, A. J., \& Ferguson, J. (2003). Workplace spirituality and employee work attitudes: An exploratory empirical assessment. Journal of organizational change management, 16(4), 426-447.

Nashori, F. (2002). Agenda Psikologi Islami. Yogyakarta: Pustaka pelajar.

Nasr, S. H. (2004). Inteligensi dan Spiritualitas Agama-Agama (trans.). Depok: Inisiasi Press.

Nikko, S. D. (1989). Psikologi Agama. Yogyakarta: Kanisius.

Nurtjahjani, H. (2010). Spiritualitas kerja sebagai ekspresi keinginan diri karyawan untuk mencari makna dan tujuan hidup dalam organisasi. Jurnal Psikologi, 7(1), 27-30.

Pawar, S.. B. (2008). Two approaches to workplace spirituality facilitation: A comparison and implications. Leadership \& Organization Development Journal, 29(6), 544-567.

Poerwadarminta, W.J.S. (1986). Kamus Umum Bahasa Indonesia. Jakarta: Balai Pustaka.

Salim, P. (1990). The Contamporary The English Indonesian Dictionary. Jakarta: Modern English Pers.

Suaedy, A. (2004). Spiritualitas dan Modernitas Antara Konvergensi dan Devergensi. Agama, Spiritulitas Baru dan Keadilan Perspektif Islam. Elga Sarapung (ed.). Yogyakarta: Pustaka Pelajar.

Tart, C. (1975). Introduction. Transpersonal Psychologies. New York: Harper \& Row.

Tobroni. (2005). The Spiritual Leadership: Pengefektifan Organisasi Noble Industry Melalui Prinsip-prinsip Spiritual Etis. Malang: UMM.

Wahyuningsih, H. (2009). Validitas Konstruk Alat Ukur Spirituality Orientation Inventory (SOI). Jurnal Psikologi, 36(2), 116-129.

Zohar, D. \& Ian, M. (2007). SQ: Kecerdasan Spiritual. Bandung: Mizan. 